\title{
FACTORS AFFECTING THE ADOPTION OF E-LEARNING IN INDONESIA: LESSON FROM COVID-19
}

\author{
Yubaedi Siron ${ }^{1}$ (D), Agus Wibowo ${ }^{2}$ (iD), Bagus Shandy Narmaditya ${ }^{3}$ (D) \\ ${ }^{1}$ Universitas Islam Negeri Syarif Hidayatullah (Indonesia) \\ ${ }^{2}$ Universitas Negeri Jakarta (Indonesia) \\ ${ }^{3}$ Universitas Negeri Malang (Indonesia) \\ yubaedisiron@uinjkt.ac.id,agus-wibowo@unj.ac.id,bagus.shandy.fe@um.ac.id
}

Received June 2020

Accepted August 2020

\section{Abstract}

This study aims to examine factors affecting the use of e-learning during the Covid-19 pandemic in Indonesia. This survey study utilized a quantitative approach to understand the relationship variables by using SEM-PLS. An online questionnaire was distributed to collect information from respondents. A total of 250 questionnaires were gathered, and 210 responses can be used for further analysis. The findings indicate that the students' intention in using e-learning was determined by several variables, including perceived enjoyment, students experience, computer anxiety, and perceived self-efficacy. These findings also confirm that both perceived ease of use and perceived usefulness can explain the students' intention in utilizing e-learning. The results provide an implication toward the importance of understanding the factors of e-learning adoption and how students can perceive e-learning as the response of the Covid-19 pandemic.

Keywords - E-learning, Students experience, Perceived enjoyment, Computer anxiety, TAM, Covid-19.

\section{To cite this article:}

Siron, Y., Wibowo, A., \& Narmaditya, B.S. (2020). Factors affecting the adoption of e-learning in indonesia: Lesson from Covid-19. Journal of Technology and Science Education, 10(2), 282-295. https://doi.org/10.3926/jotse.1025

\section{Introduction}

Covid-19 pandemic has escalated widely and gained attention among people throughout the world. The pandemic significantly affects various dimensions such as economic, social, tourism, and education in the nations (Nicola et al., 2020; Guerrieri, Lorenzoni, Straub \& Werning, 2020; Baldwin \& Tomiura, 2020). From the economic perspective, the Covid-19 shrinks the national income and inclining the unemployment rate due to inadequately of entrepreneurs in running the business. In addition, the tourism and transportation sector has experienced a downward trend, which was triggered by the implementation of social distancing or physical distancing policy (Hoque, Shikha, Hasanat, Arif \& Hamid, 2020).

In the education sector, the Covid-19 pandemic enforces the government to displace the school's teaching and learning activities to conduct home learning undergoing distance learning (e.g., web-based learning, e-learning, $\mathrm{m}$-learning). From the positive sides, this transition drives to all educational institutions in engaging the technology in the learning process. In general, a comprehensive online course requires a design such as audio and video content, which appropriate with learning materials in a particular topic. Since the rapid deployment 
of the pandemic, inevitable academia faces unpredictable challenges such as insufficient online teaching experience, preparing the context, and inadequate educational technology support (Bao, 2020).

According to Basak, Wotto and Bélanger (2018), e-learning is an information system that integrates several education dimensions, including learning material, audio, video, text, discussion, quiz, and assignment. The primary advantage for students is that e-learning allows them to reach more exceptional academic performance, career development, and social value (Alsabawy, Cater-Steel \& Soar, 2016). Furthermore, the e-learning system is closely associated with digital media and communication; thus, issues that occur in e-learning can affect the dissatisfaction of the users. Meanwhile, at the university level, the development of e-learning needs a support system from the lecturer, students, and technology specialists that make e-learning highly demanded in the learning process.

In the context of Indonesia, the implementation of e-learning faces enormous challenges. A prior study by Anggraeni and Sole (2018) mentioned that e-learning is linked with insufficient internet accessibility, technical skills, administration support, and inadequate content design. Additionally, Chaeuruman (2018); Pratama and Arief (2019) remarked that the existing issue of e-learning comes from the students' motivation in terms of student's willingness to be responsible for self-study. Indeed, Kaunang and Usagawa (2017) remarked that students did not have adequate experience with e-learning. During the Covid-19 pandemic, the use of e-learning is expected providing the same benefits and motivation in the learning process (Lynch, 2020). The lecturers or teachers can collaborate learning patterns in class through this e-learning, while students can learn varied according to their habits and speed of learning (Cheok, Wong, Ayub \& Mahmud, 2017).

In acquaintance with e-learning adoption, some studies by Alenezi and Karim (2010); Abdullah, Ward and Ahmed (2016) believe that the intention can be explained by several factors, such as perceived self-efficacy, social influence, perceived enjoyment, computer anxiety and experience in engaging e-learning. Antecedents studies have expanded a model to predict intention the use of e-learning by elaborating technological acceptance model (TAM). By using this model, some studies provided several external factors in e-learning adoption (Abdullah \& Ward, 2016; Martin, 2012; Durke et al., 2009). The primary variable of TAM is that perceived ease of use and perceived usefulness. Alsabawy et al. (2016) pointed out that perceived usefulness is the main element in understanding the failure and success of e-learning adoption. Furthermore, a previous study confirmed the validity and importance of TAM to predict technological acceptance behavior (Al-Gahtani, 2016).

The contribution of this study is that first, it aims to identify the principal factors which affect students in using e-learning during the Covid-19 pandemic. Second, the study of the intention of use e-learning has highlighted in various countries for instance in Ghana (Budu, Yinping \& Mireku, 2018), Jordan, (Al-adwan, Al-Adwan \& Smedley, 2013), Southern Africa (Esterhuyse, Scholtz \& Venter, 2016), Azerbaijan (Chang, Hajiyev \& Su, 2017) and Thailand (Punnoose, 2012; Premchaiswadi, Porouhan \& Premchaiswadi, 2012). However, little attention has been given to scholars conducting a study in Indonesia, particularly during pandemic (e.g., Berlianto, 2017; Lee, Hsiao \& Purnomo, 2014). The focus in Indonesia is underlying by remarkable changes in the use of e-learning during Covid-19 pandemic. Third, this present study highlights the literature review on what factors affecting intention to use e-learning as an impact from the Covid-19 pandemic.

\subsection{Students Experiences (SE)}

Scholars widely use the Technology Acceptance Model (TAM) in determining the adoption of technology (Teo, Lee, Chai \& Wong, 2009). The model was promoted by Davis (1986), which enhanced from the Theory of Reasoned Action (TRA) (Fishbein \& Ajzen, 1975). TAM is affected by two main variables, including perceived usefulness and perceived ease of use. Some consensus believes that experience of users can explain the perceived of the use e-learning (De Smet, Bourgonjon, De Wever, Schellens \& Valcke, 2012; Purnomo \& Lee, 2013), and perceived usefulness (Lee et al., 2014; Martin, 2012; Purnomo \& Lee, 2013; Rezaei, Mohammadi, Asadi \& Kalantary, 2008). The students who have more experience using the internet and computer tend to feel comfortable instead of students with inadequate experience or new learners (Lee et al., 2014; Purnomo \& Lee, 2013). Another study found that experience in utilizing 
e-learning can influence the intention of using e-learning in the future to support their learning activities (Premchaiswadi et al., 2012; De Smet et al., 2012; Paechter \& Maier, 2010).

H1: Experience positively influences perceived usefulness of e-learning

H2: Experience positively influences perceived ease to use of e-learning

\subsection{Perceived Enjoyment (PE)}

The concept of enjoyment is often associated with intrinsic motivation (Ryan \& Deci, 2000). Intrinsic motivation refers to happiness and satisfaction accomplished after doing a particular behavior (Doll \& Ajzen, 1992). When people are intrinsically motivated, they are more likely to move to act for pleasure and challenge rather than external encouragement. Similarly, Park, Son and Kim (2012) enhanced that perceived enjoyment shapes the extent to which activities using certain systems are considered enjoyable in itself. Antecedent studies by Davis, Lee, Nickles, Chatterjee, Hartung and Wu (1992); van der Heijden (2004) have explained a correlation between perceived enjoyment and behavior intention in utilizing the informatics system. In the e-learning context, Abdullah and Ward (2016) pointed out that factor enjoyment has positive influences on perceived ease to use and perceived usefulness. Another study, Leung, Chen and Chen (2014); Zare and Yazdanparast (2013); Hasan, Linger, Chen, Lu and Wang (2016) confirmed that perceived enjoyment can increase the students' intention in using e-learning. Those findings suggested that when students have amenities in engaging e-learning, they are more likely to have a positive attitude toward perceived usefulness and perceived ease to use.

\section{H3: Enjoyment positively influences perceived usefulness of e-learning \\ H4: Enjoyment positively influences perceived ease of use of e-learning}

\subsection{Computer Anxiety (CA)}

A solicitude toward technology is identified as a determinant factor in adopting new technology. Saade and Kira (2009) argued that technology sometimes might have an unpleasant side effect and which may include steady negative emotional states. Additionally, the side impact of technology can occur not only during interactions, but also when the idea of having to interact with a computer starts. Frustration, confusion, anger, anxiety, and emotional state can influence productivity, learning activity, social engagement, and welfare. Indeed, Venkatesh, Morris, Davis and Davis (2003) stated that the existence of technology potentially leads to anxiety behavior. According to Alenezi et al. (2010); Li and Yu (2019), computer anxiety plays an essential role in adopting e-learning in higher education. Similarly, a preliminary study by Abdullah and Ward (2016) confirmed a negative impact of computer anxiety and perceived ease of use in e-learning. Meanwhile, Chu, Graf and Rosen (2008) noted that computer anxiety is confirmed in the adoption of cellular technology, but it was not examined empirically.

H5: Computer anxiety positively influences perceived usefulness of e-learning

H6: Computer anxiety positively influences perceived ease of use of e-learning

\subsection{Perceived Self-Efficacy (PSE)}

Perceived self-efficacy is linked with individual behavior to start a motivation, cognitive resources, and particular action for the specific circumstance (Wood \& Bandura, 1989). Indeed, Bandura (1986) has explained that perceived self-efficacy will determine what actions to take, how much effort to invest, the length of perseverance, and what methods are used in challenging situations. This matter is not associated with the number of skills that individuals have but on the learner's belief that they can do under various circumstances or situations (Bandura, 2010; Rogers, McAuley, Courneya \& Verhulst, 2008). Meanwhile, Sawang, Newton and Jamieson (2013) demonstrated that the success and failure of implementing e-learning are affected by students' characteristics, including self-efficacy. An individual with a high level of self-efficacy tends to have greater competency in accomplishing certain tasks. Previous studies have found that perceived self-efficacy positively affects individual behavior related to achievement, motivation, effectiveness, and positive attitude (Bandura, 1986; Liaw, 2008). Similarly, self-efficacy improvement is closely related to perceived usefulness in using technological learning platforms (Chang et al., 2017). Also, Abdullah and Ward (2016); Abdullah et al. (2016) 
showed that self-efficacy influences perceived ease to use for e-learning, but it has a negative impact on perceived usefulness.

\section{H7: Perceived self-efficacy positively influences perceived usefulness of e-learning}

H8: Perceived self-efficacy positively influences perceived ease of use of e-learning

\subsection{Technology Acceptance Model (TAM)}

Success and failure in adopting e-learning can be associated with behavioral intention in using e-learning (Mohammadi, 2015). Dealing with this issue, the Technology Acceptance Model (TAM) is widely used to determine and explain the use of new technology (Teo et al., 2009). The technology acceptance model is related to perceived usefulness and perceived ease of use. The causality of those variables and behavioral intentions have been validated and confirmed by antecedent works such as Davis (1989); Venkatesh and Davis (2000); Lin, Fofanah and Liang (2011). Both perceived usefulness and perceived ease of use are the vital construction in determining students' intention in utilizing e-learning (Lee et al., 2014; Chang et al., 2017; Alsabawy et al., 2016; Al-Gahtani, 2016; Tarhini et al., 2014; Liaw \& Huang, 2013). The inclusion of external variables in the technology acceptance model enables researchers to determine the behavior of technology adoption. It also aims to identify specific reasons for selecting appropriate technology, which also causes scholars and practitioners to take corrective steps (Davis, Bagozzi \& Warshaw, 1989). The robust relationship between perceived usefulness and perceived ease of use shows that those who think that new technology is easy to use also find it very useful (Davis et al., 1989).

H9: Perceived ease of use positively influences perceived usefulness

H10: Perceived usefulness influences behavioral intention in using e-learning

H11: Perceived ease of use positively influences behavioral intention in using e-learning

\section{Methodology}

\subsection{Sample and Data Collection Technique}

The study involves a cross-sectional survey of faculties in a university in Indonesia. The significant advantage of this approach aims to help understand how students experience (SE), perceived enjoyment (PE), computer anxiety (CA) and perceived self-efficacy (PSE) affects behavioral intention (BI) with perceived ease of use (PEOU) and perceived usefulness (PU) as intervening variables (see Figure 1). An online questionnaire was distributed to collect information from respondents. A total of 250 questionnaires were distributed, of which 210 responses were obtained, and all the responses obtained were usable. The response rate of 84 percent is relatively high.

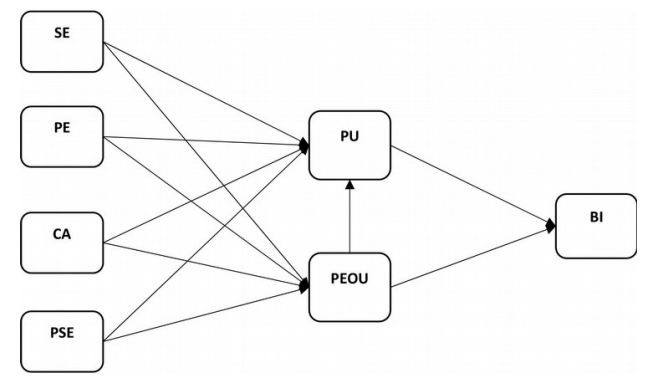

Figure 1. The conceptual model

\subsection{Measurement Development}

All the construct's measurement was adapted from previous studies with a slight modification. The questionnaire included 35 questions framing the respondent's profile and variables, which were investigated. Students' experience (SE), perceived enjoyment (PE), computer anxiety (CA), and perceived self-efficacy (PSE) were adapted instruments from Abdullah et al. (2016). Additionally, perceived usefulness (PU) and perceived ease of use (PEOU) were adapted from Davis (1989), and Behavioral intention (BI) was developed from Venkatesh and Bala (2008); Venkatesh and Davis (2000). Each construct was measured using the 5-point Likert Scale from "strongly disagree" (1) to "strongly agree" (5). 


\subsection{Assessment of the Measurement Model and the Structural Model}

The assessment of outer and inner models was performed by PLS-SEM. This method has an advantage in situations where the theory has not been adequately validated, as in our case on factors affecting the adoption of e-learning, which has not been included in previous studies on academic e-learning. The two main criteria used in PLS analysis to assess the measurement model or the outer model include validity and reliability (Ramayah, Lee \& In, 2011). In order to assess the structural model Hair, Hult, Ringle and Sarstedt, (2014) proposed five-step a structural model assessment procedure: 1) assess structural model for collinearity issue, 2) assess the path coefficient, 3) assess the level of R2, 4) assess the effect size f2, and 5) assess the predictive relevance Q2.

\section{Results and Discussions}

\subsection{Assessment of Outer Model}

Table 1 provides the information of the respondent profile based on their demographic factors and their field of disciplines.

\begin{tabular}{|c|c|c|}
\hline Characteristics & Frequency & Percentage \\
\hline \multicolumn{3}{|l|}{ Age } \\
\hline 18 year & 28 & 13.3 \\
\hline 19 year & 45 & 21.4 \\
\hline 20 year & 89 & 42.4 \\
\hline 21 year & 34 & 16.2 \\
\hline Less than 18 year & 1 & .5 \\
\hline Over 21 year & 13 & 6.2 \\
\hline \multicolumn{3}{|l|}{ Disciplines } \\
\hline Economics, social science, and humanities & 181 & 89.0 \\
\hline Sciences and Technique & 29 & 11.0 \\
\hline \multicolumn{3}{|l|}{ Level Semester } \\
\hline II & 68 & 32.4 \\
\hline IV & 66 & 31.4 \\
\hline VI & 76 & 36.2 \\
\hline \multicolumn{3}{|l|}{ Gender } \\
\hline Female & 36 & 17.1 \\
\hline Male & 174 & 82.9 \\
\hline \multicolumn{3}{|l|}{ Online learning } \\
\hline One course & 3 & 1.4 \\
\hline Two courses & 12 & 5.7 \\
\hline More than three courses & 195 & 92.9 \\
\hline
\end{tabular}

Table 1. The Profile of Respondents

Based on Table 1, the first step of outer model assessment in PLS analysis is an examination to ensure that the instrument is reliable and the variables measure it consistently. Unlike Cronbach alpha, which assumes an equivalency among the measures with the assumption that indicators are equal weight, construct reliability (used in SEM-PLS) is more concerned with individual reliability referring to different outer loadings of the indicator variables (Hair et al., 2014). The score between $0.6-0.8$ indicates good construct reliability (Hair et al., 2014). Construct validity is applied for validity analysis since it is more relevant for the social sciences (Hair Jr, Black, Babin, Anderson \& Tatham, 2006). Two sorts of validity tests were performed, convergent validity and discriminant validity.

Convergent validity is the extent to which a measure positively correlates with another measure of the same construct. In examining the convergent validity of a measure in PLS, the average variance extracted (AVE) and item loadings are evaluated (Hair, Sarstedt, Hopkins \& Kuppelwieser, 2013). AVE value higher 
than 0.50 indicates that, on the average, the construct explained more than half of its indicator variance. As such, the rule of thumb is that an AVE value greater or equal to 0.50 is acceptable (Hair et al., 2013). As shown in Table 2, the values of CR for each construct range from 0.846-0.970 exceed 0.6-0.7 as cut-off scores, so the construct reliability is achieved.

\begin{tabular}{|c|c|c|c|c|c|}
\hline Construct & Item & Loading & CR & $\begin{array}{c}\text { Cronbach } \\
\text { Alpha }\end{array}$ & AVE \\
\hline \multirow{3}{*}{ Students experience (SE) } & SE1 & 0.885 & \multirow{3}{*}{0.919} & \multirow{3}{*}{0.868} & \multirow{3}{*}{0.792} \\
\hline & SE2 & 0.907 & & & \\
\hline & SE3 & 0.877 & & & \\
\hline \multirow{3}{*}{ Perceived enjoyment (PE) } & PE1 & 0.950 & \multirow{3}{*}{0.970} & \multirow{3}{*}{0.953} & \multirow{3}{*}{0.915} \\
\hline & PE2 & 0.948 & & & \\
\hline & PE3 & 0.972 & & & \\
\hline \multirow{3}{*}{ Computer anxiety (CA) } & CA1 & 0.723 & \multirow{3}{*}{0.846} & \multirow{3}{*}{0.728} & \multirow{3}{*}{0.647} \\
\hline & CA2 & 0.817 & & & \\
\hline & CA3 & 0.867 & & & \\
\hline \multirow{3}{*}{$\begin{array}{l}\text { Perceived self-efficacy } \\
\text { (PSE) }\end{array}$} & PSE1 & 0.928 & \multirow{3}{*}{0.941} & \multirow{3}{*}{0.906} & \multirow{3}{*}{0.842} \\
\hline & PSE2 & 0.906 & & & \\
\hline & PSE3 & 0.919 & & & \\
\hline \multirow{3}{*}{ Perceived usefulness (PU ) } & PU1 & 0.922 & \multirow{3}{*}{0.958} & \multirow{3}{*}{0.934} & \multirow{3}{*}{0.884} \\
\hline & PU2 & 0.947 & & & \\
\hline & PU3 & 0.951 & & & \\
\hline \multirow{3}{*}{$\begin{array}{l}\text { Perceived ease of use } \\
(\mathrm{PEOU})\end{array}$} & PEOU1 & 0.945 & \multirow{3}{*}{0.953} & \multirow{3}{*}{0.926} & \multirow{3}{*}{0.872} \\
\hline & PEOU2 & 0.931 & & & \\
\hline & PEOU3 & 0.925 & & & \\
\hline \multirow{3}{*}{ Behavioral intention (BI) } & BI1 & 0.948 & \multirow{3}{*}{0.947} & \multirow{3}{*}{0.916} & \multirow{3}{*}{0.857} \\
\hline & $\mathrm{BI} 2$ & 0.928 & & & \\
\hline & $\mathrm{BI} 3$ & 0.900 & & & \\
\hline
\end{tabular}

Table 2. Results of Measurement (Outer) Model

Discriminant validity (Table 3) is the degree to which items differentiate among constructs or measure distinct concepts, and this was conducted by calculating and investigating the associations among the measures of possibly overlapping variables (Ramayah et al., 2011), and can be assessed by examining the correlations between the measures of potential overlapping construct. The AVE for each component should be greater than the squares of the correlation between the components and all other components (Fitch, Kadyrov, Christmas \& Kittler, 2005). On the other hand, the research model is considered to have a good discriminant when the correlation among the components is lower than the square root of the AVE (Fornell \& Larcker, 1981).

\begin{tabular}{|l|c|c|c|c|c|c|c|}
\hline & \multicolumn{1}{|c|}{ SE } & \multicolumn{1}{c|}{ PE } & \multicolumn{1}{c|}{ CA } & \multicolumn{1}{c|}{ PSE } & \multicolumn{1}{c|}{ PU } & \multicolumn{1}{l|}{ PEOU } & BI \\
\hline Students experience (SE) & 0.890 & & & & & & \\
\hline Perceived enjoyment (PE) & 0.813 & 0.956 & & & & & \\
\hline Computer anxiety (CA) & 0.706 & 0.761 & 0.805 & & & & \\
\hline Perceived self-efficacy (PSE) & 0.713 & 0.665 & 0.665 & 0.918 & & & \\
\hline Perceived usefulness (PU) & 0.771 & 0.890 & 0.722 & 0.689 & 0.940 & & \\
\hline Perceived ease of use (PEOU) & 0.816 & 0.782 & 0.782 & 0.748 & 0.851 & 0.934 & \\
\hline Behavioral intention (BI) & 0.766 & 0.826 & 0.752 & 0.745 & 0.820 & 0.843 & 0.926 \\
\hline
\end{tabular}

Table 3. Discriminant Validity 


\begin{tabular}{|c|l|r|r|r|c|}
\hline Hypotheses & Relationship & \multicolumn{1}{|c|}{ Beta } & \multicolumn{1}{c|}{ T-value } & \multicolumn{1}{c|}{ P-values } & Decision \\
\hline$H_{1}$ & $\mathrm{SE} \rightarrow \mathrm{PU}$ & 0.032 & 0.499 & 0.618 & Rejected \\
\hline$H_{2}$ & $\mathrm{SE} \rightarrow \mathrm{PEOU}$ & 0.220 & 3.370 & 0.001 & Accepted \\
\hline$H_{3}$ & $\mathrm{PE} \rightarrow \mathrm{PU}$ & 0.590 & 6.858 & 0.000 & Accepted \\
\hline$H_{4}$ & $\mathrm{PE} \rightarrow \mathrm{PEOU}$ & 0.421 & 5.937 & 0.000 & Accepted \\
\hline$H_{5}$ & $\mathrm{CA} \rightarrow \mathrm{PU}$ & 0.009 & 0.165 & 0.869 & Rejected \\
\hline$H_{6}$ & $\mathrm{CA} \rightarrow \mathrm{PEOU}$ & 0.203 & 5.937 & 0.000 & Accepted \\
\hline$H_{7}$ & $\mathrm{PSE} \rightarrow \mathrm{PU}$ & 0.021 & 0.407 & 0.684 & Rejected \\
\hline$H_{8}$ & $\mathrm{PSE} \rightarrow \mathrm{PEOU}$ & 0.156 & 2.510 & 0.012 & Accepted \\
\hline$H_{9}$ & $\mathrm{PEOU} \rightarrow \mathrm{PU}$ & 0.292 & 3.586 & 0.000 & Accepted \\
\hline$H_{10}$ & $\mathrm{PU} \rightarrow \mathrm{BI}$ & 0.370 & 3.586 & 0.000 & Accepted \\
\hline$H_{11}$ & $\mathrm{PEOU} \rightarrow \mathrm{BI}$ & 0.528 & 7.486 & 0.000 & Accepted \\
\hline
\end{tabular}

Table 4. Path Coefficients and Results of Hypotheses Testing

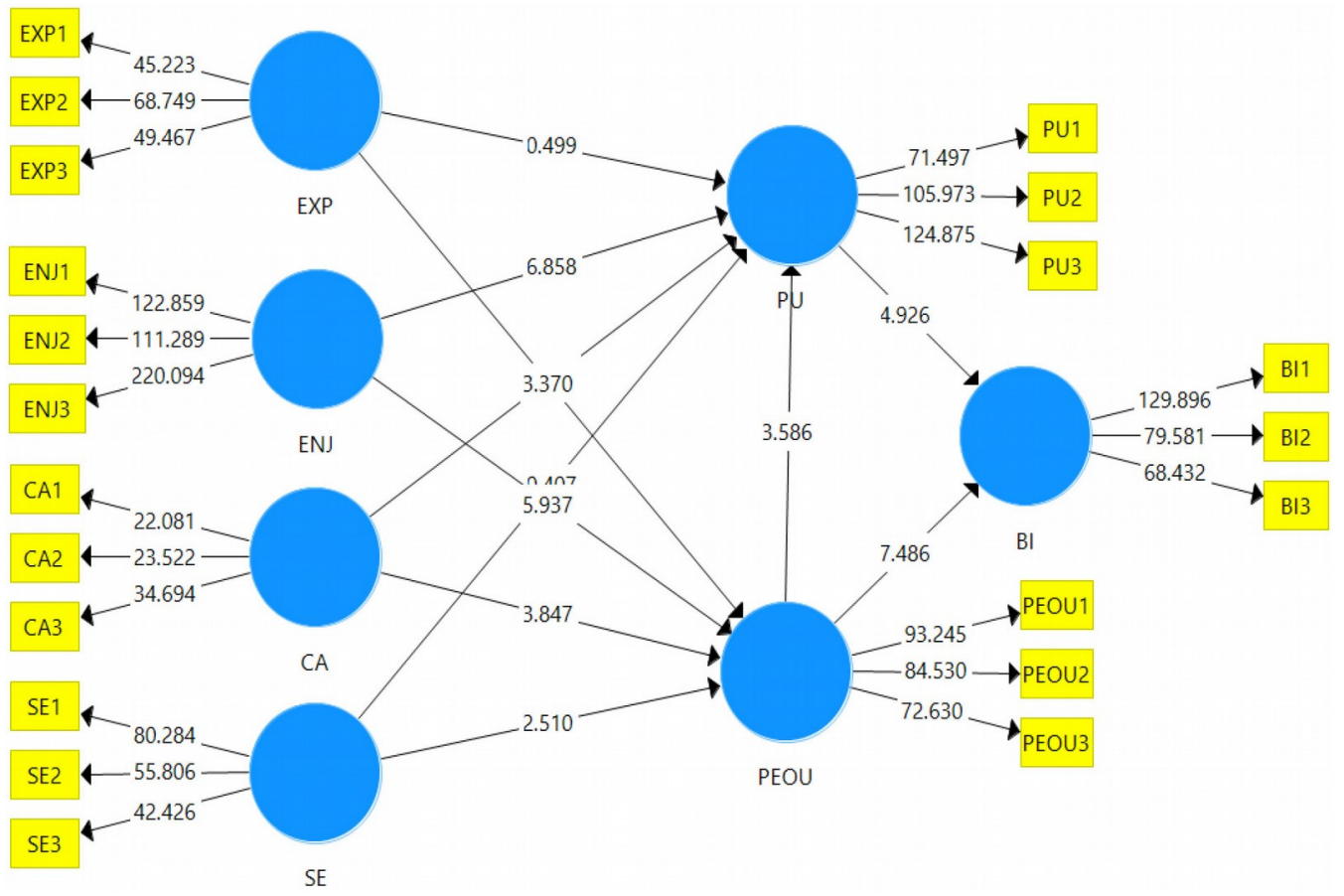

Figure 2. Measurement and Model Estimation

\subsection{Assessment of Structural (Inner) Model}

The measurement model demonstrated adequate convergent validity and discriminant validity. Therefore, the next step in PLS analysis is to develop a structural model by analyzing the inner model, which can be used to assess the relationships between construct. All the data were run using 500 bootstrapped samples, through 130 cases.

\subsection{Collinearity}

Variance Inflation Factor (VIF) coefficient is higher than 5.00 (Hair et al., 2014). The test results showed that the range of inner VIF is within $1.251-2.334$. Thus, there is no collinearity problem existing.

\subsection{Path Coefficient}

The path coefficients are also used to evaluate the structural (inner) models. The t-statistics were estimated using the bootstrap resampling procedure. The bootstrapping procedure is a non-parametric approach for estimating the precision of the PLS-SEM estimates (Henseler, Ringle \& Sinkovics, 2009). Bootstrapping results suggest the stability of the PLS-SEM estimates. In this study, all the data was run using 500 
bootstrapped samples. As shown in Table 4, all of the hypotheses were accepted since the range of $\mathrm{p}$-value for each relationship is within $0.000-0.033$, less than 0.05 .

\subsection{Model Fit}

The model R-square indicates the model's predictive accuracy (Hair et al., 2014). R-square values falling on or greater than 0.75 are considered as substantial, those that fall on 0.50 are considered moderate, and those that are 0.25 are considered as weak (Hair et al., 2014). The results showed that 82.0 percent variance of PU was explained by SE, PSE, CA, PSE, and PEOU, which is a substantial level of predictivity. Furthermore, 82.0 percent variance of PEOU was explained by SE, PE, CA, and PSE, which is a substantial level of predictivity. Lastly, 75.0 percent variance of BI was explained by SE, PE, CA, PSE, PEOU, and PU which is a substantial level of predictivity.

In addition to evaluating the $\mathrm{R} 2$ value, the $\mathrm{f} 2$ effect size test was employed. The assessment of the effect size f2 seeks to evaluate whether exogenous constructs have a substantive impact on endogenous constructs. Based on the guidelines provided by Hair et al. (2014), f2 values of $0.02,0.15$, and 0.35 respectively represent the small, medium, and large effect of the exogenous constructs on the endogenous constructs. Based on thef2, it is known the effect size of SE, PE, CA, PSE, and PEOU on PU were large size with value 0.39 . Similarly, the effect size of SE, PE, CA, and PSE on PEOU were medium size with $\mathrm{f} 2$ values is 0.25 . However, the effect size of SE, ENJ, CA, PSE, PEOU, and PU on BI were medium size with $\mathrm{f} 2$ values are 0.30 and 0.15 .

\subsection{Discussions}

Based on Table 4, it can be known that from the 11 hypotheses proposed, and eight hypotheses are accepted, while the rest is rejected. The first purpose of the study aims to examine the relationship between students' experience and influences the perceived usefulness of e-learning. The result of the study shows that the t-value is 0.499 or smaller than 1.96; thus, H1 is rejected. This finding is in contrast with some previous studies which state that experience of use can affect students' perceived usefulness. In summary, individuals who have more experience using computers, the internet and e-mail as well as storing and searching for files tend to have a more comfortable feeling about perceived usefulness e-learning systems instead of students who lack experience or new learners (Lee et al., 2014; Martin, 2012; Purnomo \& Lee, 2013; Rezaei et al., 2008).

The difference between the theory and previous studies of our findings shows that learning uses e-learning and the like according to respondents' perceptions as "forced". Thus, our research respondents have not felt the importance of using e-learning. This is consistent with the fact that before the Covid-19 pandemic struck in Indonesia, most respondents did not have adequate experience with e-learning (Kaunang \& Usagawa, 2017). Thus, when the Covid-19 pandemic broke out in Indonesia, and all teaching and learning activities moved using e-learning tools. In fact, the respondents felt difficulties instead of the importance of using e-learning. This finding becomes an entry point for policymakers at university to use more e-learning in lectures so that students feel the importance of using e-learning.

Second, this finding showed that students' experience positively influences perceived ease of use of e-learning, with a t-value of 3.370. The results of this study are relevant to recent previous works by Lee et al. (2014); Purnomo and Lee (2013), which stated that individuals who have more experience in using computers and the internet (e.g., email, storing and searching for files) tend to have a better feeling towards the perceived ease of use e-learning system rather than new learners. These findings also reinforce the study of Premchaiswadi et al. (2012); De Smet et al. (2012); Paechter and Maier (2010), who found that the experience of using e-learning can influence students' intention to use e-learning later on to support their learning activities.

Furthermore, the enjoyment factor positively influences perceived usefulness and perceived ease of use of e-learning with the t-value of 6.858 and 5.937, respectively. These findings are in line with prior studies by Leung et al. (2014); Abdullah and Ward (2016) confirmed that factor enjoyment has an impact on perceived ease of use and perceived usefulness. Indeed, these findings also reinforce the studies of Zare 
and Yazdanparast (2013); Hasan et al. (2016), which states that perceived enjoyment can increase students' intention to use e-learning. If a student finds the use of e-learning systems to be fun, it is more likely to have a positive attitude towards perceived usefulness and perceived ease to use.

The sixth and seventh hypotheses of our study show that computer anxiety positively influences the perceived usefulness of e-learning and ease of use of e-learning. The results of the hypothesis test showed that the t-values were 0.165 and 5.937 , respectively. The findings are relevant to the study of Abdullah and Ward (2016), which proves the negative influence of computer anxiety on perceived usefulness students in the context of e-learning. Similarly, this study agrees with Alenezi and Karim (2010); Li and Yu (2019), which state that computer anxiety has a link to perceived ease of use. Chu et al. (2008) emphasized that computer anxiety plays a significant role in e-learning adoption in higher education settings. In summary, computer anxiety plays a role in the adoption of cellular technology that strongly supports perceived usefulness and perceived ease of use e-learning.

However, the finding of the study shows that perceived self-efficacy does not have a positive effect on the perceived usefulness of e-learning. In contrast, perceived self-efficacy influences perceived usefulness and perceived ease of use. These findings are relevant to Bandura (1986), which remarked that self-efficacy will determine what actions should be taken, how much effort to invest, the length of perseverance, and what methods are used in challenging situations. This is related not to the number of skills a learner has, but to the learner's belief that he can do what he has, under various circumstances or situations (Bandura, 2010; Rogers et al., 2008). Indeed, Sawang et al. (2013) state that one of the primary keys to successful e-learning is related to individual characteristics, namely, the self-efficacy of students. Self-efficacy is important to build motivation that can influence one's choices, goals, emotional reactions, effort, dealing with something, and perseverance. Someone with a higher level of self-efficacy is more secure in ability and more trusted to complete particular tasks. These findings are consistent with some prior studies which stated that self-efficacy perceptions are positively predicted with behaviors related to achievements, such as motivation, effectiveness, or positive attitudes (Bandura, 1986; Liaw, 2008). Furthermore, the study results are inherent with studies that state that increased selfefficacy is highly correlated with perceived usefulness in using learning technology (Chang et al., 2017; Abdullah \& Ward, 2016).

Lastly, based on hypothesis testing, it is known that H9, H10, and H11 are accepted with t-values of 3.586, 3.586, and 7.486, respectively. Our results are relevant to the Technology Acceptance Model theory (Davis, 1989; Teo et al., 2009), which is a development of TRA (Theory of Reasoned Action) Fishbein and Ajzen (1975). The results of our study are in agreement with some preliminary works (Davis, 1989; Venkatesh \& Davis, 2000; Lin, 2011). Perceived ease of use and perceived usefulness are the most important constructions for TAM (Lee et al., 2014). They directly influence the intention of using e-learning (Chang et al., 2017; Alsabawy et al., 2016; Al-Gahtani, 2016; Tarhini, Hone \& Liu, 2014; Liaw \& Huang, 2013). There is also a relationship between perceived ease of use and perceived usefulness, which shows that perceived ease of use is a determinant of perceived usefulness. The strong relationship between perceived ease of use and perceived usefulness shows that those who think that new technology is easy to use also find it very useful (Davis, Bagozzi \& Warshaw, 1989).

\section{Conclusions}

The main purpose of this study aims to examine the principal factors that influence the use of e-learning among students of several state universities in Indonesia during the Covid-19 pandemic. We proposed several hypotheses, in which eight were accepted, and the rest were rejected. The findings showed that experience does not have a positive effect on the perceived usefulness of e-learning, but it has a positive effect on an experience positively and perceived ease of use of e-learning. Additionally, enjoyment successfully influences both usefulness and perceived ease of use of e-learning. Meanwhile, computer anxiety does not have a positive effect on the perceived usefulness of e-learning. However, it has a positive effect on perceived ease of use of e-learning. Likewise, perceived self-efficacy does not have a positive effect on the perceived usefulness of e-learning, but it does affect the perceived ease of use of e-learning. Our next finding, perceived ease of use, positively influences perceived usefulness. Finally, our findings 
confirm that perceived usefulness and perceived ease of use influences behavioral intention in using e-learning.

This study recommends to most universities in Indonesia to consider revitalizing the curriculum to be adaptive to technology, especially e-learning. This is important. Given the industrial era, 4.0 requires all e-learning based learning if graduates are adaptive and accepted in the workforce. In the context of the Covid-19 pandemic in Indonesia, both teachers or lecturers, and students should use technology in learning, one of which is e-learning. In general, a complete online course requires a complex lesson plan design, teaching materials such as audio and video content, and a technology support team. If this is not considered by stakeholders on campus, of course, the quality of learning using e-learning is insufficient.

The limitations of this study are due to the participants of the study which come from some state universities. In the future, participants should be obtained from all universities, both public and private, so that the level of readiness for the use of technology in learning can be known in detail. Future research also needs to include technology innovation (IT) as moderating variables and several similar variables, which comprehensively determine the main factors determining the use of e-learning among students.

\section{Declaration of Conflicting Interests}

The authors declared no potential conflicts of interest with respect to the research, authorship, and/or publication of this article.

\section{Funding}

The authors received no financial support for the research, authorship, and/or publication of this article.

\section{References}

Abdullah, F., \& Ward, R. (2016). Developing a General Extended Technology Acceptance Model for E-Learning (GETAMEL) by analysing commonly used external factors. Computers in Human Behavior, 56, 238-256. https://doi.org/10.1016/j.chb.2015.11.036

Abdullah, F., Ward, R., \& Ahmed, E. (2016). Investigating the influence of the most commonly used external variables of TAM on students' perceived ease of use (PEOU) and perceived usefulness (PU) of e-portfolios. Computers in Human Behavior, 63, 75-90. https://doi.org/10.1016/j.chb.2016.05.014

Al-Adwan, A., Al-Adwan, A., \& Smedley, J. (2013). Exploring students' acceptance of e-learning using technology acceptance model in Jordanian universities. International Journal of Education and Development using ICT, 9(2), 4-18.

Al-Gahtani, S.S. (2016). Empirical investigation of e-learning acceptance and assimilation: A structural equation model. Applied Computing and Informatics, 12(1), 27-50. https://doi.org/10.1016/j.aci.2014.09.001

Alenezi, A.R., \& Karim, A. (2010). An empirical investigation into the role of enjoyment, computer anxiety, computer self-efficacy and internet experience in influencing the students' intention to use e-learning: A case study from Saudi Arabian governmental universities. Turkish Online Journal of Educational Technology-TOJET, 9(4), 22-34.

Alsabawy, A.Y., Cater-Steel, A., \& Soar, J. (2016). Determinants of perceived usefulness of e-learning systems. Computers in Human Behavior, 64, 843-858. https://doi.org/10.1016/j.chb.2016.07.065

Anggraeni, D.M., \& Sole, F.B. (2018). E-Learning Moodle, Media Pembelajaran Fisika Abad 21. e-Saintika, 1(2), 57-65. https://doi.org/10.36312/e-saintika.v1i2.101

Baldwin, R., \& Tomiura, E. (2020). Thinking ahead about the trade impact of COVID-19. Economics in the Time of COVID-19, 59.

Bandura, A. (1986). The explanatory and predictive scope of self-efficacy theory. Journal of social and clinical psychology, 4(3), 359-373. https://doi.org/10.1521/jscp.1986.4.3.359 
Bandura, A. (2010). Self-efficacy. The Corsini encyclopedia of psychology, 1-3.

Bao, W. (2020). COVID-19 and online teaching in higher education: A case study of Peking University. Human Behavior and Emerging Technologies, 2, 113-115. https://doi.org/10.1002/hbe2.191

Basak, K.S., Wotto, M., \& Bélanger, P. (2018). E-learning, M-learning and D-learning: Conceptual definition and comparative analysis. E-Learning and Digital Media, 15(4), 191-216. https://doi.org/10.1177/2042753018785180

Berlianto, M.P. (2017). Anteseden dan konsekuensi kepuasan terhadap penggunaan e-learning pada mahasiswa. Jurnal Ekonomi dan Bisnis, 20(2), 229-252. https://doi.org/10.24914/jeb.v20i2.1023

Budu, K.W.A., Yinping, M., \& Mireku, K.K. (2018). Investigating the effect of behavioral intention on e-learning systems usage: Empirical study on tertiary education institutions in Ghana. Mediterranean Journal of Social Sciences, 9(3), 201-216. https://doi.org/10.36941/mjss

Chaeruman, U.A. (2018). Mendorong penerapan e-learning di sekolah. Jurnal Teknodik, 12(1), 25-31.

Chang, C.T., Hajiyev, J., \& Su, C.R. (2017). Examining the students' behavioral intention to use e-learning in Azerbaijan? The general extended technology acceptance model for e-learning approach. Computers \& Education, 111, 128-143. https://doi.org/10.1016/j.compedu.2017.04.010

Cheok, M.L., Wong, S.L., Ayub, A.F., \& Mahmud, R. (2017). Teachers' perceptions of e-Learning in Malaysian secondary schools. Malaysian Online Journal of Educational Tecbnology, 5(2), 20-33.

Chu, C., Graf, G., \& Rosen, D.W. (2008). Design for additive manufacturing of cellular structures. Computer-Aided Design and Applications, 5(5), 686-696. https://doi.org/10.3722/cadaps.2008.686-696

Davis, F.D. (1989). Perceived usefulness, perceived ease of use and user acceptance of information technology. MIS Quarterly, 13, 319-339. https://doi.org/10.2307/249008

Davis, F.D., Bagozzi, R.P., \& Warshaw, P.R. (1989). User acceptance of computer technology: A comparison of two theoretical models. Management Science, 35, 982-1003. https://doi.org/10.1287/mnsc.35.8.982

Davis, G.B., Lee, A.S., Nickles, K.R., Chatterjee, S., Hartung, R., \& Wu, Y. (1992). Diagnosis of an information system failure: A framework and interpretive process. Information \& Management, 23(5), 293-318.

De Smet, C., Bourgonjon, J., De Wever, B., Schellens, T., \& Valcke, M. (2012). Researching instructional use and the technology acceptation of learning management systems by secondary school teachers. Computers \& Education, 58(2), 688-696. https://doi.org/10.1016/j.compedu.2011.09.013

Doll, J., \& Ajzen, I. (1992). Accessibility and stability of predictors in the theory of planned behavior. Journal of personality and social psychology, 63(5), 754-765. https://doi.org/10.1037/0022-3514.63.5.754

Durkee, D., Brant, S., Nevin, P., Odell, A., Williams, G., Melomey, D., et al. (2009). Implementing e-learning and web 2.0 innovation: didactical scenarios and practical implications. Industry and Higher Education, 23(4), 293-300.

Esterhuyse, M., Scholtz, B., \& Venter, D. (2016). Intention to use and satisfaction of e-learning for training in the corporate context. Interdisciplinary Journal of Information, Knowledge, and Management, 11, 347-365. https://doi.org/10.28945/3610

Fishbein, M., \& Ajzen, I. (1975). Belief, attitude, intention and bebavior: An introduction to theory and research. Reading, MA: Addison Wesley.

Fitch, A.J., Kadyrov, A., Christmas, W.J., \& Kittler, J. (2005). Fast robust correlation. IEEE Transactions on Image Processing, 14(8), 1063-1073.

Fornell, C., \& Larcker, D.F. (1981). Evaluating structural equation models with unobservable variables and measurement error. Journal of Marketing Research, 18(1),39-50. https://doi.org/10.2307/3151312 
Guerrieri, V., Lorenzoni, G., Straub, L., \& Werning, I. (2020). Macroeconomic Implications of COVID-19: Can Negative Supply Shocks Cause Demand Shortages?, w26918. National Bureau of Economic Research.

Hair Jr., J.F., Black, W.C., Babin, B.J., Anderson, R.E., \& Tatham, R.L. (2006). Multivariate data analysis (6 ed.). New Jersey: Prentice-Hall, Inc.

Hair, J., Hult, G., Ringle, C., \& Sarstedt, M. (2014). A Primer on partial least squares structural equation modeling (PLS-SEM). London: SAGE Publications.

Hair, J., Sarstedt, M., Hopkins, L., \& Kuppelwieser, V.G. (2013). Partial least squares structural equation modeling (PLS-SEM) An emerging tool in business research. European Business Revien, 26(2), 106-121. https://doi.org/10.1108/EBR-10-2013-0128

Hasan, H., Linger, H., Chen, A., Lu, Y., \& Wang, B. (2016). Enhancing perceived enjoyment in social games through social and gaming factors. Information Technology \& People, 29(1), 99-119.

Henseler, J., Ringle, C. M., \& Sinkovics, R.R. (2009). The use of partial least squares path modeling in international marketing. In New challenges to international marketing (277-319). Emerald Group Publishing Limited.

Hoque, A., Shikha, F.A., Hasanat, M.W., Arif, I., \& Hamid, A.B.A. (2020). The effect of Coronavirus (COVID-19) in the tourism industry in China. Asian Journal of Multidisciplinary Studies, 3(1), 52-58.

Kaunang, S.T.G., \& Usagawa, T. (2017). A New Approach for Delivering e-Learning Complex Courses in Indonesia. International Journal of e-Education, e-Business, e-Management e-Learning, 7(2), 132-145. https://doi.org/10.17706/IJEEEE.2017.7.2.132-145

Lee, Y.H., Hsiao, C., \& Purnomo, S.H. (2014). An empirical examination of individual and system characteristics on enhancing e-learning acceptance. Australasian Journal of Educational Technology, 30(5), 562-279. https://doi.org/10.14742/ajet.381

Leung, K., Chen, T., \& Chen, G. (2014). Learning goal orientation and creative performance: The differential mediating roles of challenge and enjoyment intrinsic motivations. Asia Pacific Journal of Management, 31(3), 811-834. https://doi.org/10.1007/s10490-013-9367-3

Li, H., \& Yu, J. (2019). Learners' continuance participation intention of collaborative group project in virtual learning environment: an extended TAM perspective. Journal of Data, Information and Management, 1-15. https://doi.org/10.1007/s42488-019-00017-8

Liaw, S.S. (2008). Investigating students' perceived satisfaction, behavioral intention, and effectiveness of e-learning: A case study of the Blackboard system. Computers \& education, 51(2), 864-873.

https://doi.org/10.1016/j.compedu.2007.09.005

Liaw, S.S., \& Huang, H.M. (2013). Perceived satisfaction, perceived usefulness and interactive learning environments as predictors to self-regulation in e-learning environments. Computers \& Education, 60(1), 14-24. https://doi.org/10.1016/j.compedu.2012.07.015

Lin, F., Fofanah, S.S., \& Liang, D. (2011). Assessing citizen adoption of e-Government initiatives in Gambia: A validation of the technology acceptance model in information systems success. Government Information Quarterly, 28(2), 271-279. https://doi.org/10.1016/j.giq.2010.09.004

Lin, K.M. (2011). e-Learning continuance intention: Moderating effects of user e-learning experience. Computers \& Education, 56(2), 515-526. https://doi.org/10.1016/j.compedu.2010.09.017

Lynch, M. (2020). E-Learning during a global pandemic. Asian Journal of Distance Education, 15(1), 189-195.

Martin, J. M. (2012). Relationship of customer trait and situational factor determinants with the technology acceptance of self-service. Doctoral dissertation. Capella University).

Mohammadi, H. (2015). Investigating users' perspectives on e-learning: An integration of TAM and IS success model. Computers in Human Behavior, 45, 359-374. https://doi.org/10.1016/10.1016/j.chb.2014.07.044 
Nicola, M., Alsafi, Z., Sohrabi, C., Kerwan, A., Al-Jabir, A., Iosifidis, C., et al. (2020). The socio-economic implications of the coronavirus and COVID-19 pandemic: A review. International Journal of Surgery, 78, 185-193. https://doi.org/10.1016/j.ijsu.2020.04.018

Paechter, M., \& Maier, B. (2010). Online or face-to-face? Students' experiences and preferences in e-learning. The Internet and Higher Education, 13(4), 292-297. https://doi.org/10.1016/j.iheduc.2010.09.004

Park, Y., Son, H., \& Kim, C. (2012). Investigating the determinants of construction professionals' acceptance of web-based training: An extension of the technology acceptance model. Automation in construction, 22, 377-386. https://doi.org/10.1016/j.autcon.2011.09.016

Pratama, H.F.A., \& Arief, S. (2019). Pengaruh pemanfaatan e-learning, lingkungan teman sebaya, dan motivasi belajar terhadap prestasi belajar. J-PIPS (Jurnal Pendidikan Ilmu Pengetabuan Sosial), 6(1), 1-12. https://doi.org/10.18860/jpips.v6i1.7811

Premchaiswadi, W., Porouhan, P., \& Premchaiswadi, N. (2012). An empirical study of the key success factors to adopt e-learning in Thailand. In International conference on information society (i-Society 2012), 333-338. IEEE.

Punnoose, A.C. (2012). Determinants of intention to use eLearning based on the technology acceptance model. Journal of Information Technology Education: Research, 11(1), 301-337. https://doi.org/10.28945/1744

Purnomo, S.H., \& Lee, Y.H. (2013). E-learning adoption in the banking workplace in Indonesia: an empirical study. Information Development, 29(2), 138-153. https://doi.org/10.1177/0266666912448258

Ramayah, T., Lee, J.W.C., \& In, J.B.C. (2011). Network collaboration and performance in the tourism sector. Service Business, 5(4), 411-428. https:// doi.org/10.1007/s11628-011-0120-z

Rezaei, M., Mohammadi, H.M., Asadi, A., \& Kalantary, K. (2008). Predicting e-learning application in agricultural higher education using technology acceptance model. Turkish Online Journal of Distance Education, 9(1), 85-95. https://dergipark.org.tr/tr/pub/tojde/issue/16915/176477

Rogers, L.Q., McAuley, E., Courneya, K.S., \& Verhulst, S.J. (2008). Correlates of physical activity selfefficacy among breast cancer survivors. American journal of health behavior, 32(6), 594-603. https://doi.org/10.5993/AJHB.32.6.4

Ryan, R.M., \& Deci, E.L. (2000). Self-determination theory and the facilitation of intrinsic motivation, social development, and well-being. American psychologist, 55(1), 68-78.

https://doi.org/10.1037/0003-066X.55.1.68

Saade, R.G., \& Kira, D. (2009). Computer anxiety in e-learning: The effect of computer self-efficacy. Journal of Information Technology Education: Research, 8(1), 177-191. https://doi.org/10.28945/166

Sawang, S., Newton, C., \& Jamieson, K. (2013). Increasing learners' satisfaction/intention to adopt more e-learning. Education + Training, 55(1), 83-105. https://doi.org/10.1108/00400911311295031

Tarhini, A., Hone, K., \& Liu, X. (2014). The effects of individual differences on e-learning users' behaviour in developing countries: A structural equation model. Computers in Human Behavior, 41, 153-163. https://doi.org/10.1016/j.chb.2014.09.020

Teo, T., Lee, C.B., Chai, C.S., \& Wong, S.L. (2009). Assessing the intention to use technology among pre-service teachers in Singapore and Malaysia: A multigroup invariance analysis of the Technology Acceptance Model (TAM). Computers \& Education, 53(3), 1000-1009.

https://doi.org/10.1016/j.compedu.2009.05.017

Van der Heijden, H. (2004). User acceptance of hedonic information systems. MIS quarterly, 28(4), 695-704. https://doi.org/10.2307/25148660

Venkatesh, V., \& Bala, H. (2008). Technology acceptance model 3 and a research agenda on interventions. Decision Sciences, 39(2), 273-315. https://doi.org/10.1111/j.1540-5915.2008.00192.x 
Venkatesh, V., \& Davis, F.D. (2000). A theoretical extension of the technology acceptance model: Four longitudinal field studies. Management Science, 46(2), 186-204. https://doi.org/10.1287/mnsc.46.2.186.11926

Venkatesh, V., Morris, M.G., Davis, G.B., \& Davis, F.D. (2003). User acceptance of information technology: Toward a unified view. MIS quarterly, 425-478. https://doi.org/10.2307/30036540

Wood, R., \& Bandura, A. (1989). Impact of conceptions of ability on self-regulatory mechanisms and complex decision making. Journal of personality and social psychology, 56(3), 407-415

Zare, H., \& Yazdanparast, S. (2013). The causal Model of effective factors on intention to use of information technology among payamnoor and traditional universities students. Life Science Journal, 10(2), 46-50.

Published by OmniaScience (www.omniascience.com)

Journal of Technology and Science Education, 2020 (www.jotse.org)

\section{() $(1) \Theta$}

Article's contents are provided on an Attribution-Non Commercial 4.0 Creative commons International License. Readers are allowed to copy, distribute and communicate article's contents, provided the author's and JOTSE journal's names are included. It must not be used for commercial purposes. To see the complete licence contents, please visit https://creativecommons.org/licenses/by-nc/4.0/. 